\title{
ANTIBACTERIAL ACTIVITY OF THE MEDICINAL PLANT, ACALYPHA FRUTICOSA FORSSK.
}

\author{
Thambiraj, J.* \\ PG and Research Department of Botany, The Madura College (Autonomous), Madurai - 625011. \\ *E.mail: thambiraj84@gmail.com
}

ABSTRACT

The present study is to confirm the antibacterial efficacy of root extracts of the folklore medicinal plant species, Acalypha fruticosa by using three alcoholic solvents viz; petroleum ether, ethyl acetate and methanol were tested against ten human pathogenic bacteria viz., Pseudomonas aeruginosa, P. stutzeri, Escherichia coli, Micrococcus sp., Lactobacillus sp., Servatia sp., Moraxetta sp., Bacillus subtilis, B. thuriengensis, and Klebsiella pneumoniae for assessing the antibacterial properties by adapting disc diffusion method. The results of the study revealed that all extracts showed varied degree of antibacterial activity against the tested pathogens. However, the methanol extract exhibited higher inhibition zone $(21.83 \mathrm{~mm})$ against the bacterium, Bacillus subtilis. This result supports the therapeutic importance of the species, Acalypha fruticosa in curing infectious diseases and encourages the extensive use of this species in health care practices.

Keywords: Folklore Medicinal plant, Acalypha fruticosa, Antibacterial activity, Microorganisms.

\section{INTRODUCTION}

Nowadays, an increasing number of infectious agents are becoming more resistant to commercial antimicrobial compounds (Hancock et al., 2012). The necessity to develop new drugs requires varied strategies, among them, the bioprospection of secondary metabolites produced by medicinal plants (Dionisi et al., 2012).Plants have been an essential part of human society since the start of civilization. In Ayurvedic Medicine, there are numerous herbs which have been used historically for treating a large variety ofailments. Medicinal plants are the richest bio-resource of drugs of traditional systems of medicine, modern medicines, nutraceuticals, food supplements, folk medicines, pharmaceutical intermediates and chemical entities for synthetic drugs. The universal role of plants in the treatment of diseases is established by their employment in all important systems of medicine. There are many herbs on earth which lies unexplored in the field of medicine or Science. Many of the plants used today were known to the people of ancient culture throughout the world for their preservative and medicinal powers (Zaika, 1975).However several plants are used in India in the form of crude extracts. Infusions or plaster to treat common infections without scientific evidence of efficacy (Ahmad et al., 1998). Acalypha fruticosa Forssk. belongs to the family, Euphorbiaceae is one such folklore plant used in traditional system of medicine in Coimbatore district of Tamil Nadu, India. It is Gregarious bushy shrub, occurring in the tropical regions of India (Matthew, 1995). This plant species has been used as a folk remedy for the treatment ofdigestive troubles such as dyspepsia, colic and diarrhea and even to treat cholera. The root is used for gonorrhea. Leaves and roots are used in siddha system of medicine for the treatment of skin diseases (Pullaiah, 2006). The plant is also used to cure cough, cold and headache. The boiled roots are used to cure cerebral malaria (Sahoo, 2001). The crushed leaves are used to relieve fever for children. A root decoction is drunken to treat convulsions, fever, colds and swellings of the scrotum and to treat whooping cough. Root decoction is taken to snake bites, fever and ulcer of venereal origin. However, no published works are available for the antimicrobial property of root part of this plant. Hence in the present study, an attempt has been made to focus the plant in this angle and hence to assess its therapeutic potency.

\section{MATERIALS AND METHODS}

\subsection{Plant material}

Fresh root parts were collected from the population of A.fruticosapresent in the Maruthamalai Hills of Coimbatore District and washed under running tap water, air dried and then homogenized to fine powder and stored in air tight bottles.

\subsection{Preparation of extracts}

$250 \mathrm{~g}$ air-dried root powder was subjected to $250 \mathrm{ml}$ of methanol in soxhlet extraction for 8 hours $\left(50-85^{\circ} \mathrm{C}\right)$. The extracts were concentrated to dryness in a flask evaporator under reduced pressure and controlled temperature $\left(50-60^{\circ} \mathrm{C}\right)$ to yield crude residue, which was then stored in refrigerator. To obtain petroleum ether and ethyl 
acetate extracts, the same method as used to obtain methanol extract was adopted.

\subsection{Media used}

Freshly prepared nutrient agar medium was used for the culture of bacteria.

\subsection{Microorganisms}

In vitro antibacterial activity was examined for the chemical extracts of root of the study plant, against ten bacterial species which include the gram positive strains viz., Micrococcus sp., Lactobacillus sp., Bacillus subtilis, B. thuriengensis and gram negative strains viz., Pseudomonas aeruginosa, $P$. stutzeri, Escherichia coli, Klebsiella pneumoniae, Servatia sp. and Moraxetta sp. All these microorganisms were obtained from the Department of Microbiology, Tamil Nadu Agricultural University, Coimbatore. All the microorganisms were maintained at $4^{\circ} \mathrm{C}$ on nutrient agar slants until further use.

\subsection{Antibacterial assay}

The alcoholic extracts were tested for their effect against the growth of pathogenic bacteria by disc diffusion method (Bauer et al., 1966). The microrganisms, bacteria tested was inoculated into nutrient agar medium. After an incubation period of $24 \mathrm{hrs}$ at a temperature of $35^{\circ} \mathrm{C}$, three or four colonies isolated from this medium were inoculated into $4 \mathrm{ml}$ of nutrient broth and incubated for $2 \mathrm{hrs}$ at $35^{\circ} \mathrm{C}$. The cultures were adjusted with sterile saline solution to obtain turbidity. Petri dishes containing Muller- Hinton agar medium was streaked with these bacterial suspensions. Disks of $6 \mathrm{~mm}$ diameter were impregnated with the extracts of petroleum ether, methanol and ethyl acetate separately. Tetracycline is used as positive control. After equilibrium at $4^{\circ} \mathrm{C}$, the plates were incubated overnight at $37^{\circ} \mathrm{C}$ and the diameter of any resulting zones of inhibition was measured. Each experiment was repeated at least three times.

\section{RESULTS AND DISCUSSION}

The antibacterial activity of the all the alcoholic root extracts of the study species, Acalyphafruticosagenerally showed inhibitory activity against the growth of Bacillus subtilis, $B$. thuringiensis, Klebsiella pneumoniae and Pseudomonas aeruginosa. However, towards Micrococcus sp., Lactobacillus sp., Escherichia coli, Pseudomonas stutzeri, Moraxetta sp. and Serratia sp., and all these extracts showed activity with less pronounced manner (Table 1).

Table 1. Antibacterial activity of certain alcoholic root extracts of the species, Acalypha fruticosa.

\begin{tabular}{|c|c|c|c|c|c|c|c|c|c|c|}
\hline \multirow{3}{*}{ Plant extract } & \multicolumn{10}{|c|}{ Diameter of zone inhibition (mm) } \\
\hline & \multicolumn{4}{|c|}{ Gram positivebacteria } & \multicolumn{6}{|c|}{ Gram negative bacteria } \\
\hline & BS & BT & Ms & Ls & KP & EC & PS & PA & Ss & Mos \\
\hline Standard * & $\begin{array}{l}30.83 \\
\pm 0.80\end{array}$ & $\begin{array}{l}30.73 \\
\pm 0.67\end{array}$ & $\begin{array}{l}20.67 \\
\pm 0.59\end{array}$ & $\begin{array}{l}23.63 \\
\pm 0.60\end{array}$ & $\begin{array}{l}12.13 \\
\pm 0.71\end{array}$ & $\begin{array}{l}25.67 \\
\pm 0.61\end{array}$ & $\begin{array}{l}13.73 \\
\pm 0.67\end{array}$ & $\begin{array}{l}21.73 \\
\pm 0.70\end{array}$ & $\begin{array}{l}14.23 \\
\pm 0.49\end{array}$ & $\begin{array}{l}20.83 \\
\pm 0.80\end{array}$ \\
\hline $\begin{array}{l}\text { Petroleum } \\
\text { ether }\end{array}$ & $\begin{array}{l}9.67 \\
\pm 0.75\end{array}$ & - & - & - & $\begin{array}{l}8.13 \\
\pm 0.71\end{array}$ & - & - & $\begin{array}{l}7.32 \\
\pm 0.49\end{array}$ & - & - \\
\hline Ethyl acetate & $\begin{array}{l}16.13 \\
\pm 0.38\end{array}$ & $\begin{array}{l}15.16 \\
\pm 0.38\end{array}$ & $\begin{array}{l}9.73 \\
\pm 0.67\end{array}$ & $\begin{array}{l}10.73 \\
\pm 0.67\end{array}$ & $\begin{array}{l}8.77 \\
\pm 0.71\end{array}$ & $\begin{array}{l}8.73 \\
\pm 0.75\end{array}$ & $\begin{array}{l}9.77 \\
\pm 0.75\end{array}$ & $\begin{array}{l}11.73 \\
\pm 0.67\end{array}$ & $\begin{array}{l}7.77 \\
\pm 0.71\end{array}$ & $\begin{array}{l}8.77 \\
\pm 0.71\end{array}$ \\
\hline Methanol & $\begin{array}{l}21.83 \\
\pm 0.60\end{array}$ & $\begin{array}{l}20.63 \\
\pm 0.60\end{array}$ & $\begin{array}{l}8.06 \\
\pm 0.31\end{array}$ & $\begin{array}{l}8.63 \\
\pm 0.60\end{array}$ & $\begin{array}{l}10.16 \\
\pm 0.47\end{array}$ & $\begin{array}{l}9.67 \\
\pm 0.58\end{array}$ & $\begin{array}{l}9.76 \\
\pm 0.86\end{array}$ & $\begin{array}{l}7.67 \\
\pm 0.61\end{array}$ & - & - \\
\hline
\end{tabular}

BS - Bacillus subtilis ; BT - B. thuringiensis; Ms - Micrococcus sp.; Ls - Lactobacillus sp.; KP - Klebsiella pneumoniae; EC - Escherichia coli; PS - Pseudomonas stutzeri; PA - P. aeruginosa; Ss - Serratia sp.; Mos - Moraxetta sp.* Tetracycline

It is explained that the different phytochemicals like alkaloids, flavonoids, glycosides, saponins, steroids, terpenoids and phenols extracted by different solvents may be responsible for their antibacterial effects (Ananda kumar et al., 2009). Further, the methanol extract has determined to have highest inhibitory activity $(21.83 \mathrm{~mm}$ diameter inhibitory zone) against the bacterium, Bacillus subtilisand (20.63 $\mathrm{mm}$ diameter inhibitory zone) against the bacterium, Bacillus thuringiensis (gram positive) and ethyl acetate extract also showed highest inhibitory activity $(16.13 \mathrm{~mm}$ diameter inhibitory zone) against the bacterium, Bacillus subtilis and (15.16 mm diameter inhibitory zone) 
against the bacterium, Bacillus thuringiensis. It indicates the presence of effective active principle compounds in the methanol and ethyl acetate extracts of root part of $A$. fruticosa to suppress both gram negative and gram positive bacteria. It has been observed further that the methanol extracts showed significantly higher inhibitory activity against the colonial growth of Bacillus subtilis and $B$. thuringiensis, than that of the commercially available antibiotic, tetracycline. This fact shows the higher therapeutic potential of methanol extract of the study species. The ethyl acetate and petroleum ether extracts have comparatively less activity against most of the tested pathogens. It may be attributed to the presence of respective active compounds with insufficient quantities in this crude extract (Taylor et al., 2001).

This fact indicats the existence of strong antibacterial activity of rootpart of the study species, A. fruticosa and hence its effective healing property against the infectious diseases. The variation in antibacterial activity across the extracts studied may be due to the polarity of the solvents used. Significantly higher inhibitory activity of methanol extract is nearly to the commercially available antibiotic tetracycline against the bacteria, Bacillus subtilis and $B$. thuringiensis observed shows the superior healingness of root part of A. fruticosa. Proper isolation and purification of active compounds by using methanol solvent would ensure the therapeutic value of this folklore medicinal plant when it will be used commercially.

The overall study on antibacterial activity reports that the study species contains adequate variety of active compounds to reduce or check the growth of microbial colonies. It confirms the therapeutic value and hence the traditional usage of the root part of the study species, $A$. fruticosa against various ailments. Further, the alcoholic extracts of root part of this plant in general and methanol extracts and ethyl acetate in particular are suggested for the therapy of infectious diseases caused by pathogens and further studies are recommended to purify the active compounds for the formulation of new drugs, while go for commercialization.

\section{ACKNOWLEDGEMENT}

The authors are gratefully acknowledging the authorities of Tamil Nadu State Council for Science and Technology, Chennai for their financial assistance to carryout the work.

\section{REFERENCES}

Ahmed, I., Z. Mehmood and F. Mohammad, (1998).Screening of some Indian medicinal plants for their antimicrobial properties.J. Ethanophamacol.62: 183-193.

Anandakumar, A.M., S. Paulsamy, P. Sathishkumar and P. Senthilkumar, 2009.Preliminary phytochemical studies for the quantification of secondary metabolites of medicinal importance in the plant, AcalyphafruticosaForssk.J. Appl. Nat. Sci.1(1): 41-43.

Bauer, R.W., M.D.K. Kirby, J.C. Sherris and M. Turek, (1966).Antibiotic susceptibility testing by standard single disc diffusion method.American J. Clinic.Pathol.45: 493-496.

Dionisi, H.M., M. Lozada and N.L. Olivera, (2012) Bioprospection of marine microorganisms: biotechnological applications and methods. Rev. Argent.Microbiol.44:49-60.

Hancock, R.E., A. Nijnik and D.J. Philpott, (2012).Modulating immunity as a therapy for bacterial infections.Nat. Rev.Microbiol.10:243254.

Matthew, K.M. 1995. The Flora of the Tamilnadu Carnatic.(Rapinat Herbarium: Tiruchirapalli).

Pullaiah, T. 2006. Encyclopaedia of World Medicinal Plants, Daya Books, pp.1-2442.

Sahoo, 2001.Conservation and Utilization of Medicinal and Aromatic Plants, Allied Publishers, p. 80.

Taylor, J.L., S.T. Rabe, L.J. McGraw, A.K. Jager and J. van Staden, (2001).Towards the Scientific Validation of traditional medicinal plants, Plant Growth Regul.34: 23-37.

Zaika, L.I., (1975). Spices and Herbs, their antimicrobial activity and its determination.J. Food Safety, 9: 97-118. 